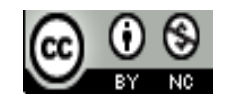

Journal of Education, Teaching and Learning is licensed under

A Creative Commons Attribution-Non Commercial 4.0 International License.

\title{
The Effect of Learning Model Multimedia-Based toward The Students' English Ability at Senior High School Of Kolaka Regency
}

\author{
Kadaruddin \\ Universitas Sembilanbelas November Kolaka, Kolaka, Indonesia \\ E-mail: kadaruddinqada@gmailcom
}

\begin{abstract}
This research was design to know the effect of learning model multimedia-based toward the students' English ablility at senior high school of Kolaka Regency. The question of the research was "Is there an effect of learning model multimedia-based toward the students' English ablility at senior high school of Kolaka Regency? The objective of the research was to find out the data whether the learning model multimedia-based has an effect toward the students' English ablility at senior high school of Kolaka Regency. The significant of the research was expected the model can be used as reference learning model to improve the students' English ablility. The design of the research was pre-experimental design. The research was conducted at the first-class students of Senior High School 1 Wundulako in Kolaka District. The data were collected by using English test which given at the pre-test and the post-test. In analysed the students' test result, which the mean score of pre-test was 33,8806 and the mean score of post-test was 69,4058 , while the t-table $18,55>2,042$ t-test. Its mean that the learning model multimedia-based has an effect toward the students' English ablility. Refering to the findings and discussions of the research, it can be concluded that the learning model multimedia-based has an effect toward the students' English ablility at senior high school of Kolaka Regency. It was based on the mean score in pre-test and post-test.Based on the conclusion of the research, the researcher suggests to the teacher, especially English teacher in Kolaka Regency to use learning model multimedia-based in teaching and learning process to improve the students' English ability.
\end{abstract}

Keywords: Learning Model Multimedia-Based

\section{INTRODUCTION}

The development of technology which is very fast must be accompanied with the ability in using it according to the needs and respective professions. Included in the field of education, the latest education technology has shown its existence. This fact has not been comparable with the individual ability of teachers in general in applying it in field of education.

Most teachers are not yet brave and reluctant to move away from using conventional educational models to technology-based education models. Therefore, there should be a maximum effort and continuously from all parties so that the use of the latest technology in the field of education can be utilized properly.

Learning in schools especially language subjects is very effective if implemented through the innovations of learning models, such as innovation of multimedia-based language learning model.

Language as a means of communication is one of the most important things in life. With language, we can express ideas, feelings, experiences, and truths in the social environment, both verbally and in writing.

As an international language, English is the most popular language in Indonesia. In Indonesia, English is used as a foreign language. To be able to adopt and master technology, information, and communication, must be supported with adequate English mastery.

In the Indonesia education curriculum, there are four language skills that must be mastered. Such as; Speaking, listening, reading, and writing. In addition to these four skills, also required mastery of language elements such as vocabulary, pronunciation, and grammar.

The problems in learning English are found, among others because English is not the mother tongue, in addition the vocabulary and grammar of students is still very limited. Without adequate vocabulary and grammar, students will have difficulty in improving their English ability. For that, English teachers are required to understand the purpose of learning English supported by the ability to use multimedia and appropriate 
strategies so that learners can improve their knowledge and English proficiency.

\section{METHOD OF THE RESEARCH}

\subsection{Design of the Research}

The design of the research is pre-experimental method with one group pre-test and post-test design. The design involves one group as pre-test $\left(0_{1}\right)$, expose to treatment $(\mathrm{x})$, and post-test $\left(0_{2}\right)$.

Table 3.1 Research design

Where:

\begin{tabular}{|l|l|l|}
\hline$\left(\mathbf{0}_{1}\right)$ & $(\mathbf{x})$ & $\left(\mathbf{0}_{2}\right)$ \\
\hline
\end{tabular}

$\left(0_{1}\right)=$ pre-test

(x) = treatment

$\left(0_{2}\right)=$ post-test

(Gay, 1981:225)

\subsection{Variable}

There were two variables involve in this research to see the effects of learning model multimedia-based toward the students' English ability.

1) The use of learning model multimedia-based was categorized as the independent variable; and

2) The students' English ability was categorized as dependent variable.

\subsection{Population and Sample}

\subsubsection{Population}

The population of this research was all students of Senior High School in Kolaka Regency. The total number of school was 35 .

\subsubsection{Sample}

The sample of this research was class first grade of Madrasah Aliyah Negeri 1 of Kolaka in Kolaka Regency. Regarding to sampling matter, the researcher used purposive sampling technique. While the sample of the research was first class, the total of the sample was 31 which consist of 20 males and 11 females.

\subsection{Instrument of the Research}

In collecting the data, there was one kind of instrument utilized in this research. English test used to acquire detail information about the students' English ability after the teaching and learning process end.

\subsection{Procedure of Collecting Data}

In collecting data, there were procedures that the researcher has to do, they are:

\subsubsection{Pre-test}

Before doing treatment, the students were given pretest to know their prior knowledge of English ability.

\subsubsection{Treatment}

1. The teacher explains to the students about learning purpose that will be achieved;
2. The teacher describes the learning scenario related with the using of learning multimedia;

3. The teacher presents the learning matter through learning multimedia that have prepared;

4. The teacher gave chance to the students to watch the matter through learning multimedia;

5. The teacher explains the learning matter that have present;

6. The teacher watchs all students' activities during the learning process;

7. The teacher repeats some matter if needed; and

8. The teacher discusses and gave conclution about the matter that have present.

\subsubsection{Post-test}

The post-test was administered after giving the treatment. The students were given a post-test to find out the effect of using learning multimedia toward the students' English ability.

\subsection{Technique of Data Analysis}

In this research, the researcher used descriptive inferential statistics to analyzing the data. Descriptive statistics used to describe the basic features of the data in the research and inferential statistics used to test the hypothesis. After gaining the data, the data was analysed by using SPSS (Statistic Product Service Solution).

\section{III.RESEARCH FINDINGS AND DISCUSSION}

\subsection{Findings}

The data where collected by administrating the test. The test was administrated twice namely pre-test and posttest. Pre-test was given before treatment and the post-test was given after treatment.

\subsubsection{Finding of analysis}

The analysis of the students finding to describe the students' result showed on the descriptive statistic. It was showed the different score of the students between the score of pre-test and post-test.

Table 5.1 The students' score in pre-test

\begin{tabular}{|l|c|c|c|c|c|}
\hline \multicolumn{5}{|c|}{ Descriptive Statistics } \\
\hline & N & Mean & $\begin{array}{c}\text { Std. } \\
\text { Deviation }\end{array}$ & Minimum & Maximum \\
\hline $\begin{array}{l}\text { Pre- } \\
\text { test }\end{array}$ & $\mathbf{3 1}$ & $\mathbf{3 3 , 8 8 0 6}$ & $\mathbf{1 2 , 5 3 9 8 0}$ & $\mathbf{2 1 , 2 1}$ & $\mathbf{7 6 , 1 1}$ \\
\hline
\end{tabular}

The table above showed that the result of the students in pre-test was the mean score was 33,8806, the standard deviation was 12,53980, while the lowest score of the students was found 21,21 and the highest score of the students in pre-test was 76,11 
Table 5.2 The Students' Score Category

\begin{tabular}{|c|c|c|c|c|c|c|}
\hline \multicolumn{7}{|c|}{ Pre-test } \\
\hline \multirow[t]{2}{*}{ No } & \multirow{2}{*}{\multicolumn{3}{|c|}{ Score }} & \multirow[t]{2}{*}{ Classification } & \multicolumn{2}{|c|}{$\begin{array}{l}\text { Students' } \\
\text { Score }\end{array}$} \\
\hline & & & & & f & $\%$ \\
\hline 1 & $\mathbf{0}$ & - & 35 & Very poor & 24 & $77,41 \%$ \\
\hline 2 & 36 & - & 55 & Poor & 5 & $16,12 \%$ \\
\hline 3 & 56 & - & 65 & Fair & - & 0\% \\
\hline 4 & 66 & - & 75 & Fairly good & - & 0\% \\
\hline 5 & 76 & - & 85 & Good & 2 & $6,45 \%$ \\
\hline 6 & 86 & - & 95 & Very good & - & $\mathbf{0 \%}$ \\
\hline 7 & 96 & - & 100 & Excellent & - & 0\% \\
\hline \multicolumn{5}{|c|}{ Total } & 31 & $100 \%$ \\
\hline
\end{tabular}

The students' score of the table above showed that the categorization of the students' English ability were 24 $(77,41 \%)$ got in very poor category, 5 students $(16,12 \%)$ got the score of poor category, and 2 students $(6,45 \%)$ got the score of good category

Table 5.3 The students' score in post-test

\begin{tabular}{|c|c|c|c|c|c|}
\hline \multicolumn{5}{|c|}{ Descriptive Statistics } \\
\hline & $\mathrm{N}$ & Mean & $\begin{array}{c}\text { Std. } \\
\text { Deviation }\end{array}$ & Minimum & Maximum \\
\hline $\begin{array}{c}\text { Post- } \\
\text { test }\end{array}$ & 31 & 69,4058 & 12,47521 & 46,82 & 97,56 \\
\hline
\end{tabular}

The table above showed that the result of the students in post-test was the mean score was 69,4058 , the standard deviation was 12,47521 , while the lowest score of the students was found 46,82 and the highest score of the students in post-test was 97,56

Table 5.4 The Sudents' Score Category

\begin{tabular}{|c|c|c|c|c|c|c|}
\hline \multicolumn{7}{|c|}{ Pre-test } \\
\hline \multirow[t]{2}{*}{ No } & \multirow{2}{*}{\multicolumn{3}{|c|}{ Score }} & \multirow[t]{2}{*}{ Classification } & \multicolumn{2}{|c|}{$\begin{array}{c}\text { Students' } \\
\text { Score }\end{array}$} \\
\hline & & & & & f & $\%$ \\
\hline 1 & $\mathbf{0}$ & - & 35 & Very poor & 0 & $0 \%$ \\
\hline 2 & 36 & - & 55 & Poor & 5 & $16,13 \%$ \\
\hline 3 & 56 & - & 65 & Fair & 7 & $22,58 \%$ \\
\hline 4 & 66 & - & 75 & Fairly good & 10 & $32,26 \%$ \\
\hline 5 & 76 & - & 85 & Good & 5 & $16,13 \%$ \\
\hline 6 & 86 & - & 95 & Very good & 3 & $9,68 \%$ \\
\hline 7 & 96 & - & 100 & Excellent & 1 & $3,23 \%$ \\
\hline \multicolumn{5}{|c|}{ Total } & 31 & $100 \%$ \\
\hline
\end{tabular}

The students' score of the table above showed that the categorization of the students' English ability were 5 $(16,13 \%)$ got in poor category, 7 students $(22,58 \%)$ got the score of fair category, 10 students $(32,26 \%)$ got the score of fairly good category, 5 students $(16,13 \%)$ got the score of good category, 3 students $(9,68 \%)$ got the score of very goog category, and 1 student $(3,23 \%)$ got the score of excellent category.

\subsubsection{Hypothesis Testing}

The t-test was formulated using SPSS program to found the effect of learning model multimedia-based. The ttest was success if $\mathrm{t}$-table $>\mathrm{t}$-count. The hypothesis testing or the t-test was showed on the table below:
Table 5.5 The Paired Sample Test of $t$-test

\begin{tabular}{|c|c|c|c|c|c|c|c|c|}
\hline & \multicolumn{8}{|c|}{ Paired Sample Test } \\
\hline & & \multirow[t]{2}{*}{ Mean } & \multirow[t]{2}{*}{$\begin{array}{c}\text { Std. } \\
\text { Deviation }\end{array}$} & \multirow[t]{2}{*}{$\begin{array}{c}\text { Std. } \\
\text { Error } \\
\text { Mean }\end{array}$} & \multicolumn{2}{|c|}{$\begin{array}{c}95 \% \\
\text { Confidence } \\
\text { Interval of the } \\
\text { Difference } \\
\end{array}$} & \multirow[t]{2}{*}{$\mathbf{t}$} & df \\
\hline & & & & & Lower & Upper & & \\
\hline $\begin{array}{l}\text { Pair } \\
\text { I }\end{array}$ & $\begin{array}{l}\text { Pre- } \\
\text { test } \\
\text { Post- } \\
\text { test }\end{array}$ & $\mathbf{3 5 , 5 3}$ & 10,67 & 1,92 & 39,44 & 31,61 & 18,55 & 30 \\
\hline
\end{tabular}

Based on the data above, the data value of t-test was bigger than the value of t-table. It indicates that there was a significant difference between the result of the students' English ability before and after treatment.

\section{IV.DISCUSSION}

The description of previous section shows the students' English ability has a significant. It was supported by the mean score of pre-test 33,8806 and post-test 69,4058 . Based on the findings above, it can be concluded that there was a significant effect of learning model multimedia-based toward the students' English ability.

After calculating the score, the researcher found the students' English ability in hypothesis testing of the students in pre-test from the mean score 33,8806 on pre-test to be 69,4058 on post-test. It was supported by the mean score post-test of the students' English ability was higher than pretest.Therefore, it can be said that the learning model multimedia-based can gave the effect toward the students' English ability. So, the $\mathrm{H}_{1}$ was accepted and $\mathrm{H}_{0}$ was rejected.

\section{Conclusion}

As has been stated before, the research was applied pre-experimental design in Senior High School in Kolaka Regency. Based on the finding and discussion, the researcher concludes as follows:

Learning Model Multimedia-based has an effect toward the students' English ability. It is proved by the meas score of the pre-test and post-test, which indicates the posttest value is higher than the pre-test while pre-test is 33,8806 and post-test is 69,4058 . Besided that, the result of statistical analysis at the level of significance is 0,05 which indicates $\mathrm{t}$-test value is higher that $\mathrm{t}$-table while $(18,55>2,042)$ with degrees of freedom (df) is 30 .

\section{References}

Alleydog, [Online] Available: https://www.alleydog.com/glossary/definition.php?term=Learning $\% 2$ 0 Model(August 8, 2017)

Dave Marshal, [Online] Available:

https://users.cs.cf.ac.uk/Dave.Marshall/Multimedia/node10.html (August 8, 2017)

Istarani, (2012). Model PembelajaranInovatif. Medan: Media Persada Kadaruddin, (2015). PeningkatanKemampuanBercerita Bahasa InggrismelaluiPenggunaan Media Film Animasi 3D bagisiswa SMA sederajat se KabupatenKolaka. DP2M Dikti: Research Report. Kadaruddin, (2015). [Online] Available: Learning Animation of 
Retelling Story Multimedia-based. https://www.youtube.com/watch?v=zMRapEyCrfc\&t=42s

Kadaruddin, (2016). InovasidanPemanfaatan Multimedia PembelajaranberbasisKomputerpada Program Studi Pendidikan Bahasa Inggris. DP2M Dikti: Research Report.

Kadaruddin, (2017). Inovation of Computer-based Learning Multimedia at English Study Program. Athen: Proceeding $3^{\text {rd }}$ International Conference.

Mayer, R. E. (Ed.). (2005). The Cambridge handbook of multimedia learning. Cambridge University Press.

Moh. Uzer Usman, Drs, (2000). Menjadi Guru Profesional. Bandung: PT. RemajaRosdakarya

MulyanaAina, (2016). [Online] Available: http://ainamulyana.blogspot.com/2016/04/model-pembelajarandalam-kurikulum-2013.html (July 17, 2017)

Nuiteq, (2016). [Online] Available: http://www.nuiteq.com/company/blog/5-benefits-of-multimedialearning(August 8, 2017)

Priyadi Adam, (2013). [Online] Available: https://adampriyadi.wordpress.com/2013/05/12/perbedaanmetode-pembelajaran-model-pembelajaran-dan-pendekatanpembelajaran/ (July 17, 2017)

Rouse Margaret, [Online] Available: http://searchmicroservices.techtarget.com/definition/multimedia (August 8, 2017)

Thesaurus, [Online] Available: https://www.tel-

thesaurus.net/wiki/index.php/Multimedia learning (August 8, 2017)

Zainal Aqib, (2014). Model-model, Media danStrategiPembelajaranKontekstual (Inovatif). Bandung: YramaWidya. 